\title{
Erratum: Early evolution of evolutionary thinking: teaching biological evolution in elementary schools
}

\author{
Rita Campos ${ }^{*}$ and Alexandra Sá-Pinto*
}

The authors detected some errors in the representation of evolutionary relationships between the species used to illustrate the activity about systematics (Campos and Sá-Pinto 2013).

Figure eight A: The evolutionary tree contains groups that don't represent the most supported hypotheses about the relationship between species (bats are more closely related to primates - human and gorilla - than to mouse; lizards are most probably more closely related to birds than to turtles; cod fish and pouting are more closely related to terrestrial vertebrates than to sharks). Therefore, this tree should be corrected and used taking those errors in consideration. To have access to updated data on the evolutionary relationship between these and other species please visit the web project "The tree of life" (http://tolweb.org/tree/).

Figure eight B: For a correct representation of the relationship between species, where it reads "bat", it should read "rabbit".

Received: 7 January 2014 Accepted: 7 January 2014

Published online: 25 April 2014

\section{Reference}

Campos R, Sá-Pinto A (2013). Early evolution of evolutionary thinking: teaching

biological evolution in elementary schools. Evolution: Education and

Outreach, 6:25. http://www.evolution-outreach.com/content/6/1/25.

Submit your manuscript to a SpringerOpen ${ }^{\circ}$ journal and benefit from:

- Convenient online submission

- Rigorous peer review

- Immediate publication on acceptance

- Open access: articles freely available online

- High visibility within the field

- Retaining the copyright to your article

Submit your next manuscript at $\boldsymbol{\wedge}$ springeropen.com 